UDC 669.334.6

\title{
KINETICS OF THERMAL DECOMPOSITION OF DASHKASAN COBALT ORE
}

\author{
N.V. Yusifova, A.A. Heydarov, A.M. Pasajanov, M.M. Ahmadov, T.M. Ilyasly
}

\author{
Acad. M. Nagiyev Institute of Catalysis and Inorganic Chemistry \\ National Academy of Sciences of Azerbaijan \\ H. Javid Ave. 113, Baku AZ 1143, Azerbaijan \\ E-mail: naile.yusifova@inbox.ru
}

Recieved 30.01.2018

\begin{abstract}
Kinetics of thermal decomposition of Dashkasan cobalt mineral in the temperature range of 973$1123 \mathrm{~K}$ was studied. Activation energy was determined. According to the value of activation energy $(236,5 \mathrm{~kJ} / \mathrm{mol})$ it revealed that the decisive stage of ore processing is the decomposition of ore depending on temperature. Note that the enrichment of ore was performed due to the use of pyrometallurgy method by melting of ore at $1673 \mathrm{~K}$. When melting ore, 5\% of carbon was added into furnace burden to form a reductive medium. The resultant alloy contains $15-20 \%$ of cobalt. Rate constants of thermal decomposition of cobalt ore at different temperatures were calculated. Kinetic parametrs of the decomposition processing of cobaltine were calculated using generalized topokinetic Kolmoqorov-Erofeev equation. Unlike well-known works the study was performed with natural mineral of cobaltine.
\end{abstract}

Keywords: Cobalt ore, activation energy, mineral, kinetics, thermal decomposition, cobaltine

\section{INTRODUCTION}

Cobalt ores have different mineralogical and chemical compositions and are manycolored. In ores the amount of cobalt may change in a wide range - from $100 \%$ to several percents. When amount of cobalt is $0.15 \%$ or less in non-oxidized complex ores (with sulfide and arsenyl), the production of it is economically profitable. In Azerbaijan, the main reserves of cobalt are located in the South Dashkasan deposit. The main mineral of this deposit is cobaltine. The work shows that as ore contains hard-melting cobalt and alumosilicate compounds cobalt cannot be fully yielded. When processing mineral with $20 \%$ of chloride acid, the yield of cobalt is $77.4 \%$; with $2 \mathrm{~N}$ sulfate acid it makes up $76.7 \%$; in the dissolution of sulfatized mass in water it stands at $973 \mathrm{~K} 88.52 \%$ of Co yields. When processing the primary sample with ammonia solution, more than $51 \%$ of cobalt does not go into solution[1-5]. The reason of partial extraction of cobalt from ore is the poor solubility of ore minerals in water, acid and alkali solutions. To make cobalt into maximum soluble form, first crystal cage of minerals in ores must be destructed. This process was performed in two manners thermal decomposition of ore samples in inert medium and oxidization of ore samples by atmospheric air. These operations had first been carried out in 1935-1938 at the Giredmet Institute where the pyrometallurgical enrichment process of floatation concentrate of Dashkasan deposit performed. During the process, metals and cobalt were generated from "speiss" obtained at 1573-1613K. As the paper [6] shows, $15-20 \%$ Co alloy (speiss) is generated from floatation of Dashkasan ore while $3-4 \%$ of cobalt containing concentrate, reductive melting of concentrate as compared with primary raw material cobalt becomes condensed 200 times. The next process is performed by processing an alloy using hydrometallurgy method. Since dissolution of alloy in acid goes weakly or partially, considerable emission of toxic $\left(\mathrm{AsH}_{3}\right.$ and $\left.\mathrm{H}_{2} \mathrm{~S}\right)$ gases is observed. Note that $98 \%$ of cobalt can be separated from raw material by floatationpyrological enrichment method. Since the process is multi-stage, the use of high energy comsuming equipment, and the emission of arsenium containing toxic gases into 
atmosphere poses ecological danger, we examined a new way of Dashkasan cobalt ore processing. To find extraction condition of Dashkasan cobalt ore, it is necessary to study kinetic laws of thermal decomposition of cobaltite mineral in ore. Kinetic results of thermal decomposition of ore cobaltine can be a theoretical basis for revealing technological parameters of Dashkasan ore processing. Since cobalt ore has a complex and multi component composition, different parallel-consistent reactions which are determined by kinetic and diffusion, or various factors, can be occured. Since the research of real kinetic laws of separate stages of the process is experimentally complex, we studied formal kinetics of the process. Study of kinetic laws is important for selection of optimum mode of ore burning and explanation of its mechanism.

The paper [7] examined the thermal decomposition of synthetic cobalt which was generated from powdery elements. It should be stated that mechanical and chemical properties of synthetic cobaltite differs from properties of the mineral of natural cobalt. As mentioned above, cobalt can be found in ore both together with separate minerals and in crystal cage of $\mathrm{Fe}, \mathrm{Cu}, \mathrm{Al}$ minerals. Unlike well-known known works, all the processes were analyzed, and natural cobalt mineral and kinetic parameters calculated. Kinetic parameters of experimental results were calculated through the use of generalized topokinetic Kolmoqorov-Erofeev equation:

$$
\alpha=1-\mathrm{x}=1-\mathrm{C} / \mathrm{C}_{0}=1-\exp \left(-\mathrm{k} \tau^{\mathrm{n}}\right) \quad[1],
$$

where:

$\alpha$ - conversion degree of purposeful component, $\mathrm{x}$-non-conversion degree of purposeful component

$\mathrm{k}$ - rate constant of reaction,

$\tau$ - time of experiment,

n- kinetic parameter shows reaction composition,

$\mathrm{C}_{0}$ and Cexpress relevant densities of purposeful component at $\tau=0$ and $\tau$.

Twice logarithm of equation (1) gives the following expression:

$$
\lg [-\lg (1-\alpha)]=\operatorname{nlg} \tau+\operatorname{lgk}
$$

Tangent of inclination of line to abscissa axis equals to " $n$ " kinetic parameter, when $\lg \tau=0$ intersection point of it with axis of ordinatesequals to lgk.

Using $\mathrm{K}=\mathrm{nR}^{1 / \mathrm{n}}$ equation we calculate rate constant $(\operatorname{lnK})$ of the reaction.

$$
\lg K=\lg n+1 / n \lg R \text {. }
$$

According to graphic method detection, of $\mathrm{K}$ and $\mathrm{n}$ demands many experiments and since kinetic parameters are not obtained precisely, kinetic parameters in the Kolmogorov-Erofeev equation were performed by the simplex method of I.N.Beloglazov [8]. This method reduces the volume of experimental results unlike graphic method and simplifies calculation method. Detection of precise parameter values of $\mathrm{K}, \mathrm{n}$ and $\mathrm{C}_{0}$ is performed through the use of the simplex method of analytical equation. Thus, when using the simplex method the equation of the kinetic curve goes over into the dimensionless form of the equation corresponding to the experimental values of $\mathrm{C}_{\mathrm{i}}$ and $\tau$. In any time for time interval we can refer to $\Delta \tau_{1}$.

$$
\Delta \tau_{1}=\varphi_{\mathrm{i}+1}-\tau \mathrm{i}=\varphi_{1}\left(\mathrm{C}_{\mathrm{i}} ; \mathrm{C}_{\mathrm{i}+1}\right) \text { and } \mathrm{S} \tau=\tau \mathrm{i}+1 / \tau_{\mathrm{i}}=\varphi_{2}\left(\mathrm{C}_{\mathrm{i}} ; \mathrm{C}_{\mathrm{i}+1}\right)
$$


Where $\Delta \tau_{i}$ is a time interval for two $\tau_{i}$ and $\tau_{i+1}$ moments; S $\tau$-simplex of time similarity.

Through the resolving $\Delta \tau_{1}=\varphi_{1}\left(\mathrm{C}_{\mathrm{i}} ; \mathrm{C}_{\mathrm{i}+1}\right)$ and $\mathrm{S} \tau=\varphi_{2}\left(\mathrm{C}_{\mathrm{i}} ; \mathrm{C}_{\mathrm{i}+1}\right)$ equation, we can determine measurement indications of dependences which conform to the Erofeev-Kolmogorov equation and clarify kinetics of chemical process.

According to this method, the equation (1) can be expressed for two different time moments $\tau_{i}$ and $\tau_{i+1}\left(\Delta \tau_{1}=\tau_{i+1}-\tau_{i}\right)$ by the following equations:
1) for time moment $\tau_{\mathrm{i}}$ :
$\ln ^{1 / \mathrm{n}}\left(\mathrm{C}_{\mathrm{o}} / \mathrm{C}_{\mathrm{i}}\right)=\mathrm{k}^{1 / \mathrm{n}} \cdot \tau_{i}$
2 ) for time moment $\tau_{i+1}$ :
$\ln ^{1 / n}\left(C_{o} / C_{i+1}\right)=k^{1 / n} \cdot \tau_{i+1}(3)$

According to the simplex method reaction, the composition (n) and rate constant $\mathrm{k}$ are found by the following formula:

$$
\begin{gathered}
\mathrm{n}=\frac{\ln \left(\ln \mathrm{s}_{\mathrm{c}, \mathrm{i}+1} / \operatorname{lnSc,i)}\right.}{\ln S \tau} \\
\mathrm{k}=\frac{1 \ln \mathrm{nc}_{\mathrm{i}} \mathrm{i}}{\mathrm{\pi}_{\mathrm{i}}^{\mathrm{n}}-\left(\mathrm{S}_{\mathrm{\tau}}^{\mathrm{n}}-1\right)}
\end{gathered}
$$

where $\mathrm{S}_{\mathrm{c}, \mathrm{i}}=\frac{\mathrm{C}_{\mathrm{i}}}{\mathrm{Ci}+1}$ and $\mathrm{S}_{\mathrm{c}, \mathrm{i}+1}=\frac{\mathrm{C}_{\mathrm{i}+1}}{\mathrm{Ci}_{\mathrm{i}}+2} \Delta \tau_{\mathrm{i}}$ and $\Delta \tau_{\mathrm{i}+1}\left(\mathrm{~S}_{\tau, i+1}=\mathrm{S}_{\tau, \mathrm{i}}=\mathrm{S}_{\tau}\right)$

is the simplex of density similarity in time interval for two moments $\Delta \tau_{\mathrm{i}}-\tau_{\mathrm{i}}$ and $\tau_{\mathrm{i}+1}$.

\section{RESULTS AND DISCUSSIONS}

Influence of temperature and of Dashkasan cobalt ore in inert medium are experimental time on thermal decomposition given in Table 1.

Table 1. Influence of time and temperature on thermal decomposition.

\begin{tabular}{|c|c|c|c|c|}
\hline \multirow{2}{*}{ Temperature, $\mathrm{K}$} & \multicolumn{4}{|c|}{ Thermal decomposition of ore, \% } \\
\cline { 2 - 5 } & $300 \mathrm{sec}$ & $600 \mathrm{sec}$ & $1200 \mathrm{sec}$ & $2400 \mathrm{sec}$ \\
\hline 973 & 4.9 & 5.7 & 7.9 & 14.5 \\
\hline 1023 & 6.8 & 12.5 & 27 & 56.0 \\
\hline 1073 & 9.5 & 15.2 & 34.5 & 65.5 \\
\hline 1123 & 11.4 & 21.5 & 39.8 & 81.2 \\
\hline
\end{tabular}

According to experimental results in Table 1 we define $\mathrm{n}$ and $\mathrm{k}$ parameters which conform to Kolmogorov-Erofeev equation.
Value of $\mathrm{n}$ parameter in $\Delta \tau_{1}, \Delta \tau_{2}$ and $\Delta \tau_{3}$ time moment at $700^{\circ} \mathrm{C}$ temperature is calculated as follows:

$$
\text { Then } \mathrm{n}=\frac{\ln (\operatorname{lnSc}, 3 / \operatorname{lnSc}, 2)}{\ln \mathrm{S}}=\frac{\ln (\ln 1,077 / \ln 1,0238}{\ln 2}=\frac{\ln 3,26989}{\ln 2}=\frac{1,18475}{0,6931}=1,7
$$

Value of K constant is found according to formula [5]:

$$
\mathrm{K}=\frac{1}{\pi_{1}^{n}} \cdot \frac{\ln \mathrm{S}_{\mathrm{c}} 1}{\left(\mathrm{~S}_{\tau}^{\mathrm{n}}-1\right)}=\frac{1}{300^{1,4 \mathrm{~s}}} \cdot \frac{\ln 1.00848}{\left(2^{1,48}-1\right)}=0,000001429=0,1429 \cdot 10^{-5}
$$

Table2. Rate constants of thermal decomposition of Dashkasan cobalt ore at different temperatures. 


\begin{tabular}{|c|c|c|c|}
\hline $\mathrm{T}, \mathrm{K}$ & $\mathrm{K}$ & $\operatorname{lgK}$ & $\mathrm{k} \cdot 10^{-5}, \mathrm{san}^{-1}$ \\
\hline 973 & 10.277 & -5.8453 & 0.1428 \\
\hline 1023 & 9.7775 & -5.24916 & 0.5634 \\
\hline 1073 & 9.319 & -4.7099 & 1.95 \\
\hline 1123 & 8.9047 & -4.259 & 5.5 \\
\hline
\end{tabular}

Depending on temperature the values of $\mathrm{K}$ are shown respectively by Arrhenius equation (Fig. 1).

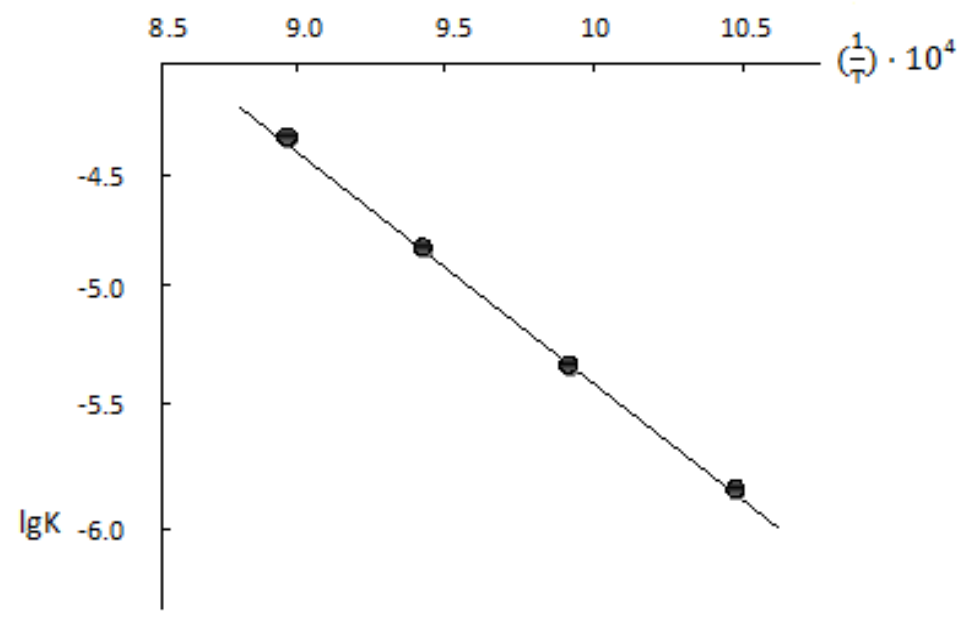

Fig. 1. Dependence of logarithm of rate constant of thermal decomposition of cobalt ore on temperature.

$$
\operatorname{tg} \alpha=\frac{\mathrm{E}_{\mathrm{ak}}}{2,303 \cdot \mathrm{R} \cdot \xi}
$$

Activation energy is calculated using the following equation [9-12]:

$$
\mathrm{E}=2,303 \cdot \mathrm{R} \cdot[\operatorname{tg} \alpha] \cdot \xi
$$

Where $\alpha$-inclination of line to abscissa axis, $\xi$-ratio of scale in abscissa axis to scale in axis of ordinates, is called correction constant.
As to Arrhenius coordinates in Fig.2 according to rate constant curve of thermal decomposition of Dashkasan cobalt ore, the value of $\operatorname{tg} \alpha$ is 1.235 .

$$
\xi=\left(1: 0,5 \cdot 10^{-4}\right):(1: 0,5)=10^{4}
$$

Where $\quad \mathrm{E}=2,303 \cdot 8.314 \cdot 1,235 \cdot 10^{4}=236467 \mathrm{C} \cdot \mathrm{mol}=236,5 \mathrm{kC} \cdot \mathrm{mol}$

Value of activation energy (236.5 place in kinetic regions at 973-1123 K $\mathrm{kJ} / \mathrm{mol}$ ) and size of kinetic parameter temperatures.Value of activation energy, $(n>1)$ show that thermal decomposition of comparison of dependence curve of $\operatorname{lgK}$ on ${ }^{1} / \mathrm{T}$ cobaltite mineral in Dashkasan cobalt ore takes 
with Arrhenius curve of V.D. Chunaeva went to show that the decisive stage in the decomposition of ore cobaltite is the decomposition stage where cobaltite depends on temperature.

\title{
REFERENCES
}

1. Heydarov A.A., Yusifova N.V. Research into leaching conditions of cobalt from highsilica contained cobalt ores with mineral acis. Azerbaijan Chemical journal. 2016, no. 2, p. 32.

2. Heydarov A.A., Ahmedov M.M., Yusifova N.V., Veliyev B.S., Mahmudov M.K. Extraction of cobalt at complex processing of non-traditional cobalt-containing raw material. Kimya Problemleri - Chemical Problems. 2015, vol. 13, no.1, pp. 69-73. (In Azerbaijan).

3. Heydarov A.A., Yusifova N.V., Ahmadov M.M., Guliyeva A.A. Research into sulfatisation of cobalt containing non-ferrous cake. Kimya Problemleri - Chemical Problems. 2015, vol.13, no. 3, pp. 262-266. (In Azerbaijan).

4. Heydarov A.A., Kashkay Ch.M. Research into percolation leaching of valuable components out of enriched wastes of Dashkesan mining and processing plant. Kimya Problemleri - Chemical problems. 2016, vol. 14, no.1, pp.17-25. (In Azerbaijan).

5. Heydarov A.A., Kashkay Ch.M. Recovery of precious metals from Dashkesan mineral tailings through the use of combined methods. Azerbaijan Chemical Journal. 2016, no. 3, pp. 121-129.
6. Heydarov A.A., Yusifova N.V. Extraction of cobalt from final tailings of ore-processing plant. International Symposium "Environmental and engineering aspects for sustainable living”. Euro-eco. Hannover, 2015, p. 31.

7. Chunaeva V.D., Muldagaliyeva R.A., Isabaev S.M., Polukarov A.N. Kinetics of thermal decomposition of CoAsS. Russian Journal of Non-Ferrous Metals. 1990, no. 1, pp. 31-33.

8. Beloglazov I.N., Klyushin S.A., Kurochkina M.I. Determination method of parameters in kinetic Erofeev-Kolmogorov equation. Journal of Applied Chemistry. 1986, no. 10, pp. 22332337. (In Russian).

9. Emmanuel N.M., Knorre D.G. Chemical kinetics course. Moscow, 1974, 400 p.

10. Zhanq M., Zhu G., Zhao Yu., Feng X. A study of recovery of copper and cobalt from copper-cobalt oxide ores by ammonium salt roasting. Hydrometallurgy. 2012, vol. 129130, pp. 140-144.

11. Kashkay M.A. Petrology and metallogeny of Dashkesan and other iron ore deposits of Azerbaijan. Moscow: Nedra Publ., 1965, 228 p.

12. Mahmudov A.I. Mineralogy of cobalt ores. Moscow: Nedra Publ., 1982, 234 p.

\section{DAŞKӘSON KOBALT FILIZININ TERMIKI PARÇALANMASININ KINETIKASI}

\author{
N.V. Yusifova, A.Ә. Heydorov, A.M. Paşacanov, M.M. Ohmədov, T.M. İlyaslı \\ Azarbaycan Milli EA-nın M.F.Nağlyev adına Kataliz va Qeyri-üzvi kimya İnstitutu \\ AZ1143 Bakl, H.Cavid pr.,29 \\ e-mail naile.yusifova@inbox.ru
}

\begin{abstract}
Daşkəsən kobalt filizindəki kobaltin mineralının 973-1123 K temperatur intervalında termiki parçalanmasının kinetikası tadqiq edilmişdir. Aktivlaşmə enerjisi təyin edilmişdir. Aktivlaşmə enerjisinin qiymatina $(236,5 \mathrm{kc} / \mathrm{mol})$ göra müayyən edilmișdir ki, filizin işlənmasinda tayinedici marhala filizin temperaturdan asılı olaraq parçalanmasıdır. Filizin zanginlaşməsi prosesi pirometallurgiya üsulu ilo filizi $1673 \mathrm{~K}$ temperaturda aritməkla aparılmışdır. Filizi əridərkən reduksiyaedici mühit yaratmaq üçün şixtaya 5\% karbon alava edilir. Alınmış arintinin tarkibinda 15-20\% kobalt olur. Müxtalif temperaturlarda kobalt filizinin termiki parçalanmasının sürat sabitlari hesablanmışdır. Kobaltinin parçalanma prosesinin kinetik parametrlari Kolmoqorov-Yerofeyevin ümumilaşmiş topokinetik tənliyinin
\end{abstract}


köməyi ila hesablanmışdır. Məlum işlardən farqli olaraq bütün proseslər təbii kobaltin mineralı üzərində aparllıb.

Açar sözlor: kobalt filizi, aktivlaşmə enerjisi, mineral, kinetika, termiki parçalannma, kobaltin.

\section{КИНЕТИКА ТЕРМИЧЕСКОГО РАЗЛОЖЕНИЯ ДАШКЕСАНСКОЙ КОБАЛЬТОВОЙ РУДЫ}

\section{Н.В. Юсифова, А.А. Гейдаров, А.М. Пашаджанов, М.М. Ахмедов, Т.М. Ильясль}

Институт Катализа и Неорганической химии им. акад. М.Нагиева

Наииональной АН Азербайджана

AZ 1143 Баку, пр.Г.Джавида,113;

e-mail:naile.yusifova@inbox.ru

Исследована кинетика термического разложения в температурном интервале 973-1123 К минерала кобальтина в составе Дашкесанской кобальтовой руды. Определена энергия активации. По значению энергии активации процесса (236.5 kДюсмоль) установлено, что при разработке руды определяющей стадией является разложение руды в зависимости от температуры. Процесс обогащчения руды проведен методом пирометаллургии расплавлением руды при температуре 1673 К. При расплавлении руды для создания восстановительной среды в шихту добавлено 5\% углерода. Полученный расплав содержит 15-20\% кобальта. Рассчитаны константы скорости разложения кобальтовой руды при различных температурах. Кинетические параметры прочесса разложения кобальтина рассчитань с помощью обобщенного топокинетического уравнения Колмогорова-Ерофеева. В отличие от известных работ все процессы проведены с природным минералом кобальтином.

Ключевые слова: кобальтовая руда, энергии активации, минерал, кинетика, термическоге разложение, кобальтин. 